\title{
EFFECT OF ACETAZOLAMIDE ON THE SECRETION OF PANCREATIC JUICE INDUCED BY DOPAMINE IN DOGS
}

\author{
Kazuhiko IWATSUKI and Shigetoshi CHIBA \\ Department of Pharmacology. Shinshu University School of Medicine, Matsumoto 390, Japan
}

Accepted December 7, 1980

Carbonic anhydrase catalyzes the hydration of carbon dioxide to bicarbonate. Since Van Goor (1) reported that carbonic anhydrase is present in a significant concentration in the pancreas, the role of this enzyme in pancreatic secretion has been of great interest. In 1941. Tucker and Ball (2) reported that sulfanilamide, an inhibitor of carbonic anhydrase, did not influence the secretion of pancreatic juice, as induced by secretin in dogs. However, Birnbaum and Hollander (3) observed that acetazolamide, a more potent inhibitor of carbonic anhydrase. inhibited the pancreatic secretion induced by secretin. These workers suggested that carbonic anhydrase plays an important role in the secretion of bicarbonate by this gland.

Hashimoto et al. (4) reported that dopamine caused an increase in the secretion of pancreatic juice. The mode of action was found to be quite similar to that of secretion, that is a large volume of juice with a higher concentration of bicarbonate were produced (5). We investigated the effect of acetazolamide on the secretion of pancreatic juice, as induced by dopamine.

Six mongrel dogs, weighing 12-15 kg. were anesthetized with sodium pentobarbital i.v. A polyethylene tube was inserted into the main pancreatic duct for collection of the pancreatic juice. Polyethylene cannulae were inserted into the gastroduodenal and splenic arteries and used to perfuse the pancreas with the animal's own heparinized blood from the left femoral artery by means of a Harvard peristaltic pump (Model 500-
1200). All experiments were performed under constant pressure at $100 \mathrm{mmHg}$. Details of the preparation have been described elsewhere $(4,6)$. The rate of pancreatic secretion was measured using a drop counter. Bicarbonate concentration was measured by a modified Van Slyke manometric technique (7). Dopamine hydrochloride (Sigma) and sodium acetazolamide (Takeda) were dissolved in $0.9 \%$ saline solution. Dopamine was injected into a rubber tube connected to the arterial cannula, and acetazolamide was given into the femoral vein. Statistical analysis was carried out by means of the Student's $t$-test.

A flow of pancreatic juice was observed under the resting state, in all preparations. Acetazolamide did not affect either the resting secretion or the bicarbonate concentration in the juice. Dopamine in doses of 1.3 or $10 \% \mathrm{~g}$ i.a. caused a prompt increase in the secretion of pancreatic juice, as reported previously (4). The dopamineinduced secretion was suppressed by treatment with acetazolamide in a dose of 10 $\mathrm{mg} / \mathrm{kg}$ i.v. Summarized data obtained from 6 experiments are shown in Table 1. Dopamine caused a diphasic response of the perfusion blood flow, that is a decrease followed by a slight increase. However, the responses of perfusion blood flow to dopamine were not affected by treatment with acetazolamide. Dopamine produced dose-dependent increases in the concentration of bicarbonate in the pancreatic juice. Pretreatment with acetazolamide. 
Table 1. Effect of acetazolamide on the secretion of pancreatic juice and on the bicarbonate concentration induced by dopamine

\begin{tabular}{|c|c|c|c|c|}
\hline \multirow{2}{*}{ Treatment } & \multicolumn{2}{|c|}{$\begin{array}{l}\text { Volume of pancreatic } \\
\text { juice }(a \mid)\end{array}$} & \multicolumn{2}{|c|}{$\begin{array}{c}\text { Bicarbonate concentration } \\
\text { (mmole/liter) }\end{array}$} \\
\hline & Control & $\begin{array}{l}\text { Acetazolamide } \\
\text { treatment }\end{array}$ & Control & $\begin{array}{l}\text { Acetazolamide } \\
\text { treatment }\end{array}$ \\
\hline Resting state & $114 \pm 32$ & $105 \pm 36$ & $15.5 \pm 2.6$ & $14.2 \pm 2.3$ \\
\hline \multicolumn{5}{|l|}{ Dopamine } \\
\hline $1 \mu \mathrm{g}$ & $162+48$ & $85 \pm 26$ & $28.2 \pm 2.5$ & $18.6 \pm 2.2^{*}$ \\
\hline $3 \mu \mathrm{g}$ & $496 \pm 94$ & $238 \pm 63^{*}$ & $40.1 \pm 3.6$ & $21.2 \pm 3.1^{* *}$ \\
\hline $10 \mu \mathrm{g}$ & $1120 \pm 125$ & $660 \pm 98^{*}$ & $62.5 \pm 3.7$ & $39.5 \pm 4.5^{* *}$ \\
\hline
\end{tabular}

Each value is the mean $\pm S$.E. from 6 experiments. Pancreatic juice was collected for $15 \mathrm{~min}$ in the resting state or from the beginning until the end of the secretory response when dopamine was given i.a. Volume of the juice and bicarbonate concentration in the juice were then measured. Acetazolamide $(10 \mathrm{mg} / \mathrm{kg})$ was administered i.v. $5 \mathrm{~min}$ before the collection of pancreatic juice in the resting state or before the injection of dopamine. Significantly different from control, "P<0.05," $\mathrm{P}<0.01$.

bicarbonate concentration in the pancreatic juice induced by $1 \mathrm{~kg}$ of dopamine was significantly reduced and was highly significant at a dose of 3 or $10 \mathrm{~kg}$ of dopamine.

Previously we reported that dopamine produced marked increases in the secretion of pancreatic juice in the $\operatorname{dog}(4,5)$. The responses to dopamine were modified by haloperidol, a dopamine receptor antagonist (6). We suggested that there were specific receptors for the secretion of the pancreatic juice by dopamine and that dopamine may play a physiological role in the secretory mechanism of the dog pancreas. Furthermore, infusion of secretin increased the dopamine content in the pancreatic tissues (8). This observation suggested that dopamine plays a role in secretin-stimulated secretion. Since dopamine was shown to increase cyclic AMP content in certain tissues (9) and since cyclic AMP caused a pancreatic secretion (10), dopamine, like secretin, may regulate water and bicarbonate secretion through the mediation of adenyl cyclase (11). In the present experiments, acetazolamide decreased the volume of pancreatic juice induced by dopamine. Bicarbonate concentration in the juice was also significantly reduced. These results suggest that carbonic anhydrase activity in the pancreas may in part control the dopaminergic mechanism of the pancreatic secretion in dogs. Our findings are similar to those of Birnbaum and Hollander (3). who reported that acetazolamide was capable of suppressing the volume and bicarbonate responses to secretin in dogs. Sulfanilamide may not affect the secretion because of an insufficient inhibition of the enzyme (2). The potency of sulfanilamide is 400 times less active than that of acetazolamide (12).

\section{REFERENCES}

1) Van Goor, H.: Die Verbreitung und Bedeutung der Carbonanhydrase. Enzymologia 8, 113-128 (1940)

2) Tucker, H.F. and Ball, E.G.: The activity of carbonic anhydrase in relation to the secretion and composition of pancreatic juice. J. biol. Chem. 139, 71-80 (1941)

3) Birnbaum, D. and Hollander, F.: Inhibition of pancreatic secretion by the carbonic anhydrase inhibitor 2-acetylamino-1,3,4-thiadiazole-5sulfonamide, diamox (\$6063). Am. J. Physiol. 174, 191-195 (1953)

4) Hashimoto, K., Satoh, S. and Takeuchi, O.: Effect of dopamine on pancreatic secretion in the dog. Brit. J. Pharmacol. 43, 739-746 (1971) 
5) Furuta, Y., Iwatsuki, K., Takeuchi, O. and Hashimoto, K.: Secretin-like activity of dopamine on canine pancreatic secretion. Tohoku J. exp. Med. 108, 353-360 (1972)

6) Furuta, Y., Hashimoto, K., Iwatsuki, K. and Takeuchi, O.: Effects of enzyme inhibitors of catecholamine metabolism and of haloperidol on the pancreatic secretion induced by L-dopa and dopamine in dogs. Brit. J. Pharmacol. 43, 77-84 (1974)

7) Natelson, S.: Routine use of ultramicro methods in the clinical laboratory. Am. J. Clin. Path. 21, 1153-1172 (1951)

8) Furuta, Y., Hashimoto, K., Ishii, Y. and Iwatsuki, K.: Modification by drugs of the secretagogue effect of dopamine on the pancreas. Brit. J. Pharmacol. 51, 225-230 (1974)

9) Forn, J., Krueger, B.K. and Greengard, P.:
Adenosine $3^{\prime}, 5^{\prime}$-monophosphate content in rat caudate nucleus demonstration of dopaminergic and adrenergic receptors. Science 186, 1118-1120 (1974)

10) Takeuchi, O., Satoh, S. and Hashimoto, K.: Secretory and vascular response to various biogenic and foreign substances of the perfused canine pancreas. Japan. J. Pharmacol. 24, $57-73(1974)$

11) Case, R.M., Johnson, M., Scratcherd, T. and Sherratt, H.S.A.: Cyclic adenosine 3',5' - monophosphate concentration in the pancreas following stimulation by secretin, cholecystokinin-pancreozymin and acetylcholine. J. Physiol. 223, 669-684 (1972)

12) Roblin, R.O., Jr.: The preparation of heterocyclic sulfonamides. J. Am. Chem. Soc. 72, 4890$4892(1950)$ 